\title{
Alliance building process as inhibiting factor for SME international alliances
}

This study examines how the alliance building process affects the intention to enter into international alliances in the case of SMEs. From a psychological perspective (Perceived Behavioural Control) we analyse the alliance building process as an inhibitor of the international collaboration intention, considering to what extent the experience affects the intention of the partners involved. The study explores these hypotheses based on a sample of 220 Spanish SMEs. The results provide empirical evidence showing that the intention to develop international alliances is negatively affected by the search and the selection process as well as by the negotiation of the agreement, which reduces the intention to establish an international agreement. On the other hand, the intention is moderated by the experience of the SME' manager. Moreover, there is a negative relationship between the extent of SMEs manager's international experience and the intention to develop an international alliance.

Code JEL: L26; L24; M13

\section{Introduction}

Traditionally, research on the internationalization of business and entrepreneurship has highlighted the difficulties and risks of this process (Lu and Beamish, 2001). International alliances $^{1}$ and cooperation agreements in general, allows SMEs to gain access to additional resources and enter markets in ways not possible for a single firm (Burgel and Murray, 2000; Hoffmann and Schaper-Rinkel, 2001). International alliances appear to be a fundamental factor for SMEs in mitigating situations with high transaction costs, and for ruling out initial hypotheses regarding the size and experience needed to operate abroad (McDougall et al, 1994; Lu and Beamish, 2001). These cooperative relationships search for synergies that aim to reduce risk and to obtain economies of scale and scope (Coviello and McAuley, 1999; McDougall et al., 2000; Lu and Beamish, 2001, 2006). Despite the advantages offered by international alliances, empirical evidence shows a low level in their use. Thus, for example in the EU case, one fifth of European SMEs develop international activities and only 5\% have subsidiaries and joint ventures abroad (Observatory of European SMEs, 2010). Lu and Beamish (2001), Fink et al. (2008), and Hopp and Lucas (2014) point out that the use of international alliances entails several obstacles and barriers derived from factors as the coordination of two or more partners, the search for the right partner, the emergence of goal conflicts, the lack of trust and understanding, and cultural differences (McDougall and Oviatt, 1999; McDougall and Oviatt, 2000; Lu and Beamish, 2001, 2006; Audretsch, 2009). These obstacles reveal that the alliance cooperation itself is not a guarantee of successful entry in international markets.

\footnotetext{
${ }^{1}$ International alliances are defined as joint ventures, licensing, distribution/ production agreements (Bierly and Gallagher, 2007).
} 
Although a body of research has focused on the role of managers' cognitive structures in operating alliances (Dwyer et al., 1987; Osborn and Hagedoorn, 1997; Speakman et al., 1998; Holmberg and Cummings, 2009; Swoboda et al., 2011), there is a dearth of research on their role on alliance building. The manager of a firm is who rationally coordinates organizational activities, even though the strategic process of the firm is typically viewed as flows of information and decisions, detached from the insights of the managers involved (Hambrick and Mason, 1984; Carpenter et al., 2004). Literature suggests that firms' decision to pursue alliances as a strategic goal is the result of the reflection of managers in the organization, and their choice of action is based on their idiosyncratic experiences, motives, and influences of people in their social environment (Finkelstein and Hambrick, 1996; Carpenter et al., 2004). Managers' perceived ease or difficulty of entering into and implementing alliances are likely to impact their predisposition to support alliance formation (Larson, 1992; Gulati, 2008). In this context, literature suggests that alliance building involves a complex decisional process, which is not without difficulty for managers. Snowoda et al. (2011) stress the need for adequate strategic, structural and cultural fit between partners, and Reuer and Ariño (2007) highlight the preparation of the contract as a source of difficulties in the early stages of alliances. Therefore, following Ajzen's formulation $(1991 ; 2002)$, the intention of the individual to develop an action will be conditioned by the perceived ease or difficulty of performing the behaviour.

With this backdrop, our research focuses on the impact of difficulties raised in the early stages of alliance building on managers' intention to enter international alliances. Our study employs the psychological foundations of intentional theory (Ajzen 1991; 2002), which has been characterized as insightful in its ability to understand and explain individual behaviours and intentions (Hill et al., 1996; Kilber et al., 2014), and as a theoretical lens for examining these difficulties. Our study uses the perceived behavioural control (PBC) perspective to explore the intention to enter international alliances, and the moderating role of managers' experience. From the PBC viewpoint, the intention to develop an action is conditioned by the degree of control that the manager has on that action and it is moderated by a series of endogenous factors that affect the alliance building process. We include the manager's experience in international alliances as a moderating factor; this is considered from a triple perspective: as a factor of learning (Cohen and Levinthal, 1990), as a motivational factor (Baron, 2004; 2006), and as a factor to generate social governance mechanisms between the partners (Poppo and Zenger, 2002).

We test our hypotheses using a representative sample of Spanish SMEs with experience on international activities. We focus our analysis on commercial cooperation to test how the alliance 
building process affects SMEs intention to develop international cooperation. Spanish SMEs, although important on Spanish economy, are lagging behind the European average in terms of internationalization and the use of international cooperation (Observatory of European SMEs, 2010). Research on Spanish SMEs highlights the lack of firm's experience in developing geographic markets, the manager's deficiencies in knowledge of foreign languages, the low added level of products (Observatory of European SMEs, 2010), and the high level of family businesses (Fernandez and Nieto, 2006). Fernandez and Nieto (2006) argue that international cooperation agreements are established in an informal and unstructured way, most of them with international suppliers. Moreover, they point out that family businesses are unlikely to cooperate because founders are reluctant to make changes and to decentralize the decision-process. As for the perception that Spanish entrepreneurs have on international cooperation, next to the classics and negative aspects highlighted in literature (e.g. the problems in the choice of partner, the need for an adequate coordination, the problems derived of opportunistic behaviour), they consider the process of establishing the agreement as complex and tedious (Consejo Superior de Cámaras, 2007). Therefore, by investigating the inhibiting factors of international cooperation perceived by SMEs, and acknowledging the importance of international growth by SMEs for the Spanish economy, this study has important implications both for firms and government support organizations.

In addition, this research makes a number of theoretical contributions. First, it adds significant new empirical knowledge to the strategic alliance literature (Gulati, 2008). In previous studies on strategic alliances, the alliance building process has been considered a key element for the alliance success (Snowoda et al., 2011; Gulati, 1998); however, our view emphasizes the alliance building as inhibitory effect on the formation of strategic alliance. Moreover, literature on strategic alliances has extensively studied the obstacles that managers face in the process of alliance formation (Gulati, 1998; Chwoka and Raith, 2012), emphasizing the importance of barriers (Das and Teng, 2000). However, none of them attempts to understand the dissuasive effect of these obstacles in the formation of alliances. This study demonstrates the importance of the alliance building process in the intentions of strategic alliance and responds to the call for new research to analyze from a cognitive and social psychological perspective how such processes affect the formation of alliances (Gulati, 2008).

Second, our study contributes to the literature on the internationalization of SMEs (Lu and Beamish, 2001; Majocchi and Zucchella, 2003; Bell et al., 2004). Our study provides empirical evidence on the role of barriers in the internationalization of SMEs (Yaprak, 1985; Leonidou, 1995, or Bell, 1977). Previous literature points out the attitudinal barriers to emphasize the 
deterrent power of the barriers in the early stages of internationalization, especially in the case of SME exporters. Our work continues this line, but applied to the case of international alliances.

Third, our paper is framed in the theory of managerial decision (Delios et al., 2004; Inkpen and Ross, 2001), where previous research has examined the factors that affect the internationalization decision (McDougall and Oviatt, 2000; Manolova, et al., 2002; McDougall, et al., 1994). This paper advances the theory by examining the formation of decision from the PBC perspective. This research analyses the internationalization decision, drawing on the factors that discourage or mitigate the SME manager' intention to internationalize, arguing that both internal and external control are important in the decision-making process. In this regard, we emphasize the role of experience as moderator of internal and external control, and propose a model of intention based on the effect of inhibitors and moderating factors. We go beyond the traditional analysis of experience in the context of alliance success by combining the three aspects of the experience: learning (Cohen and Levinthal, 1990; Das and Teng, 2000; Anand and Khanna, 2000); previous experiences with the same partner (Zollo et al., 2002); and experience in time (Wood and Bandura, 1989; Baron, 2004, 2006; Baron and Ensley, 2006). We extend the research on the role of experience in the development of alliances (Gulati, 1999) and on its influence on the intention of international collaboration.

In the next section, we present a concise overview of relevant literature on international collaboration in order to generate hypotheses. The following section describes our research methodology, including data collection and measures. Afterwards, our data analysis and results are provided. Then, we present the discussion and managerial implications of the findings, and we conclude with limitations and suggestions for future research.

\section{Literature review}

\section{$P B C$ as antecedent of behavioural intention}

In social psychology literature, intention is the best predictor of planned behaviour; models focused on intention are subject of considerable interest in entrepreneurship research (Bird, 1988; Katz and Gartner, 1988; Krueger and Brazeal, 1994; Liñán and Chen 2009). In the entrepreneurial context, Thompson (2009, p. 676) defines intention as 'a self-acknowledged conviction by a person that they intend to set up a new business venture and consciously plan to do so at some point in the future'. The theory of planned behaviour (TPB) (Azjen, 1991; 2002) posits that intention, a function of behavioural beliefs, is a significant predictor of subsequent behaviour. The TPB represents an extension of the Theory of Reasoned Action (TRA) (Ajzen 
and Fishbein, 1980), which as major advancement over more widely disseminated intention models, is the addition of a third predictive component, the Perceived Behavioural Control (PBC) (Ajzen, 1991, 2002).

PBC is defined as the perception of the easiness or difficulty in the fulfilment of the behaviour of interest (Ajzen, 1991; 2002). It is, therefore, a concept quite similar to perceived self-efficacy ${ }^{2}$ (Bandura, 1997), and it is also very close to Shapero and Sokol's (1982) vision about perceived feasibility. In all three cases, the important thing is the sense of control regarding the fulfilment of individual behaviours. Conner and Armitage (1998), White, et al. (1994), and Kang et al. (2006) point out the notion that control comes in two forms: internal control, based on factors that come from within the individual (such as self-efficacy and motivation); and external control, based on factors that come from outside the individual (such as task difficulty, access to necessary resources, and trust). Thus, the perceived difficulty PBC refers to the perceived ease or difficulty of performing the behaviour in question, implicitly taking account of internal and external control factors. Moreover, Ajzen (1991; 2002) argues that perceptions of control will be influenced by previous behavioural outcomes; in principle, relationships between past and future behaviour should be mediated by intentions and PBC.

\section{Alliance Building Process as inhibitor of the intention to enter into international alliance}

Alliance building process, as Swoboda et al. (2011) point out, entails important decisions for firms' managers. We particularly focus on the ex-ante stages of the alliance building process; to what these authors circumscribe to the "partner selection and negotiation/agreements: the former refers to such aspects as identifying and assessing potential partners, while the latter element covers aspects like negotiations about objectives, rights and duties or partners' contributions, forms of contract and potential routes to value creation" (Swoboda et al., 2011; p.276). The search and selection of partner consists on choosing to ally with someone who has the resources you need and whom you can induce, via your own stock of resources, to collaborate with you. Ideally, the complementarities of both firms' resources and capabilities produce synergies for both firms. At this stage, tasks such as the definition of the partner profile as well as its identification through adequate channels of search take place. In the negotiation stage, Hoffmann and Schlosser (2001) point as main tasks the negotiation of objectives, the definition of each partners' role, the contribution and payoff system and the organizational and control mechanisms. A crucial element at this stage is drawing up the contract (Reuer and Ariño, 2007), which is not without difficulty.

\footnotetext{
${ }^{2}$ Bandura (1977) defines self-efficacy as people's beliefs about their capabilities to produce performances that influence events affecting their lives.
} 
Therefore, the intention to enter an international collaboration will be conditioned, from the PBC perspective, by the perceived ease or difficulty of performing these actions which in turn are determined by the complexity of such tasks. Moreover, in the intention we consider one factor that moderates the task's control: managers' experience. Thus, the role of PBC in codetermining behaviours should be greater when the person has experience with the targeted behaviour (Ajzen and Madden, 1986), because this experience will lead to greater accuracy in the perceptions of control. The experience affects the internal control in two ways: (1) from the learning perspective (Cohen and Levinthal, 1990) as experience accumulates knowledge, and (2) from the motivation and beliefs, and consequently, from the degree of optimism with which actions are perceived (Slovic, 2000; Baron, 2004, 2006). In this way, Baron (1998) and Grégoire et al (2011) point out that optimism tends to overestimate the capabilities, and therefore the internal control of a situation; moreover, Carsrud and Brännback, (2011) explain that the experience moderates optimism and the assessment of internal control and capabilities as the reality is known. Experience also affects the external control as in the case of establishing alliances with partners that had already collaborated.

The above considerations lead us to argue that the intention to enter into an international alliance is a balance between inhibiting and moderating factors of the alliance building process. -Insert Figure1 about here

\section{Hypotheses}

Search and selection of partner(s) as inhibitor of the intention of SMEs' managers to enter into an international alliance

The question of who to cooperate with has been widely analysed in literature (see for example, Hagedoorn et al., 2000). Essentially, the criteria used from the resource based theory is supported by the contribution of individual strengths and by the search for complementary resources (Gulati, 2000; Hernan et al., 2003), which leads to vertical or horizontal cooperation. Additionally, in the case of SMEs, numerous contributions have suggested that size is an important criterion in the search for partners (Lu and Beamish, 2001; 2006; Raymond and StPierre, 2013), and have pointed out that unbalanced cooperation is unusual. Prior research has suggested that partner selection is an important task that influences international cooperation success (Hatfield and Pearce, 1994; Hagedoorn et al., 2000; Baum et al., 2002; Bell et al., 2001; Winch and Bianchi, 2006), since the ability to achieve the strategic objectives of cooperation depends on the skills and resources of their partners (Gulati, 2000; Pathak and Zibarras, 2010). 
The searching and selection of partner(s) can be a difficulty depending on the perceptions of SMEs' managers. In international collaboration, this task poses an additional difficulty, the high uncertainty resulting from operating in foreign markets for which an exhaustive search and acquisition of information is necessary to reduce uncertainty (Lu and Beamish, 2001). This task includes preparing the needs' dossier to establish the international agreement, defining the profile of the partner, and pursuing through the appropriate channel (Swoboda et al., 2011). A first source of difficulty emerges from the strategic formulation period (Gulati, 2000; Hageddorn et al., 2000; Shrader, 2001; Kalantaridis, 2004; Chrisman, et al., 2005), in which the promoter has to consider the identification of reasons to be carried out the internationalization by means of a cooperation agreement, and needs to prepare the initial dossier. A second impediment comes from the identification of possible collaborating partners. In this sense, Geringer (1991) advanced the distinction between the selection criteria related with tasks and that related with partners. Task-related criteria are associated with the strategic fit among partners (resources, capabilities and skills) while partner-related criteria are linked with organizational fit, being both criteria complementary. Finally, another obstacle arises from the definition of channels used to search for partners. Zhou et al. (2003) identified three different search channels: market-based (open information from media, advertisement or open trade information), social relation-based (information derived from social networks, self-initiative or collegial referral) and institutionbased search channels (information derived from government sponsorship). A bad choice may increase the difficulty in finding the right partner. Therefore, this set of difficulties in the search and selection process, may be an inhibitor factor in the intention to develop international alliances. From the PBC perspective, this will have a negative influence on internal control, which will also negatively affect the manager' intention to develop an international alliance. Considering these ideas, we formulate that:

H1: The greater the perceived difficulty on the selection of partners by SMEs' managers, the lower the intention to pursue an international alliance.

Negotiation of the agreement as inhibitor of the intention of SMEs' managers to enter into an international alliance

In the alliance building process the second group of tasks in the establishment of international alliance is the negotiation of the agreement (Swoboda et al., 2011; Chwolka and Raith, 2012). International alliance, as a voluntary arrangement between two or more partners, requires the adoption of appropriate governance structures -both formal and social- (Das, and Teng, 2001; Poppo and Zenger, 2002; Liu et al., 2009). Social governance structures depend on 
trust to encourage desirable behaviour and take the form of participatory decision making and joint problem solving. Formal governance structures rely primarily on contracts, whose objectives foster cooperation and suppress opportunistic behaviours, detailing the roles and responsibilities of partners to solve conflicts (Mohr and Spekman, 1994), coordinate common tasks (Geringer and Herbert, 1989) and distribute results (Gulati, 1998; Gulati et al., 2000). Poppo and Zenger (2002) emphasize that contracts are explicit and represent promises or obligations to perform actions in the future. They also point out that contracts propose particular behaviour patterns and specify the duties of all parties, along with penalties for violation of the agreement and the pre-specified behavioural boundaries. Therefore, it will be necessary to plan the agreement, organize tasks and roles among partners, assign decision-making capabilities, as well as to create control mechanisms such as meetings and reports. In this task, one of the most frequent reasons for failure and for the emergence of difficulties in the cooperation is that the relationship is not properly built (Dhanaraj and Beamish, 2004; Chrisman et al., 2005; Lu and Beamish, 2006; Raymond and St-Pierre, 2013).

Prior research on negotiation has suggested that an initial source of difficulties in the cooperation comes from the bargaining power of companies and the resources they bring to the agreement (Inkpen and Beamish, 1997). This difficulty stems from three domains: the resources owned of each party, the importance of the agreement to each party and the similarity of interests of each party (Inkpen and Beamish 1997; Reuer and Ariño, 2007). A second source of difficulties in cooperation arises from the realization of the contract. Williamson (2002), Poppo and Zenger (2002), and Reuer and Ariño (2007) emphasize that an agreement is subject to hazards which make it impossible to predict all situations, both internal and external. Hence, it is unfeasible to have a contract which fully covers all of the governing partners' exchanges and relationships in an agreement. A third source of difficulties derives from the negotiation of partner's contribution to alliance, finance, and payoff systems (Williamsom, 2002; Reurer and Ariño, 2007). A fourth group of difficulties arises from the shared roles and functions among partners and from the definition of the coordination of tasks. Finally, a fifth group of difficulties derives from the definition of the strategic planning for the cooperation agreement. All these tasks and difficulties are conditioned by the greater or lesser ease of communication between partners (Gulati, 2000). From the PBC perspective, these difficulties in alliance building process will have a negative influence on the internal and external control of SMEs' managers, which will also negatively affect the intention to develop an international alliance. Taking these ideas into account, we formulate that: 
H2: The greater the perceived difficulty on the negotiation of the agreement by SMEs' managers, the lower the intention to pursue an international alliance.

Selection vs. negotiation: which one prevails as inhibitor of the intention of SMEs' managers to enter into an international alliance?

Within the context of this study, it is important to know which of the two tasks is more prevalent in the inhibition of the intention to develop an international alliance. As pointed out above, the search and selection of partners is a task of detection -through the analysis and diagnosis of needs- and identification of potential partners. This task is sometimes an important process of reflection, which finally concludes with the specification of the partner profile. But searching for and deciding who to cooperate with can be difficult for the manager which may have limited information and financial resources with which to gather critical information in the search for potential collaborators (Julien and Ramangalahy, 2003; Raymond and St-Pierre, 2013). To solve this shortcoming, occasionally and in order to simplify this task, mangers tend to choose partners with whom they have already collaborated (Hatfield and Pearce, 1994; Gulati et al., 2000; Hopp and Lukas, 2014); this makes the process of international alliance easier, but as Gulati et al. (2000) indicate, it can decrease the efficiency of the agreement's results. Also, there are certain initiatives, in the case of the EU, which provide support to managers in finding partners and in the launching of joint ventures (e.g. the Your Europe Business Portal, the Enterprise Europe Network, and public agencies such as government organizations and chambers of commerce). In other cases, managers are assisted by outsider advisors, such as consultants, accountants, and lawyers (Chrisman et al., 2005). But in general, alliance building for internationalisation search for and selection of partners are a tasks with high uncertainty as a result of the need to identify and obtain information about the right partners (Kirby and Kaiser, 2003; Bierly and Gallagher, 2007). Regarding the second group of tasks, negotiation and arrangements, research findings indicate that entrepreneurs are highly optimistic (Hmieleski and Baron, 2009), which at this stage may result in a low concreteness of the business plan. Also, this lack of concreteness may be due to low levels of partner implication (Gulati, 1998; Deeds and Hill, 1998), or because internationalisation is not a strategic priority in the operations of the company ( $\mathrm{Lu}$ and Beamish, 2001). However, as it will not be until the implementation /management phase of the agreement when this problem is faced, we consider that the selection stage involves greater difficulty than the negotiation stage and that it is an important obstacle in internationalisation. Therefore, we expect: 
H3: The perceived difficulty in partner selection will have a greater effect on the inhibition of SMEs' managers to enter into an international alliance than the perceived difficulty in the agreement negotiation.

Experience of SMEs' managers in international alliances as a facilitator of international alliance intention

Prior research has suggested that experience in the development of international agreements is a learning factor that facilitates their success (see for example, Gulati, 2000; Hagedoorn et al., 2000; Al-Laham, et al., 2008). Early studies in this field considered that previous experiences facilitate the dossier preparation (Chrisman et al, 2005) as well as partner search and selection (Mohr and Spekman, 1994; BarNir and Smith, 2002). Similarly, having previous experience in the negotiation stage reduces its difficulty (Gulati, 2000; Hagedoorn et al., 2000; Raymond and St-Pierre, 2013) as well as the elaboration of the international cooperation contract (Lu and Beamish, 2001; Reuer and Ariño, 2007). The knowledge derived from past experiences increases self-efficacy and motivation of the SME' manager, enhancing the internal control of the alliance building process and consequently decreasing the perception of its difficulties. Taking these ideas into account, we formulate that:

H4a: There is a positive and significant relation between previous experiences of SMEs' managers on international collaboration and the intention to enter into an international alliance.

Research on alliance also points out that the high uncertainty derived from the partner selection process favours the tendency to establish agreements with previous partners. In this way, as mentioned above, Williamson (2002) and Poppo and Zenger (2002) emphasized the impossibility of predicting all the situations that may arise in cooperation agreements. For that reason, Das and Teng (1998) support that the trust created with the partner, as a consequence of previous experiences, contributes to the level of confidence in partner cooperation, which implies that it will be easier to communicate and work together ( $\mathrm{Lu}$ and Beamish, 2001; Thorgren and Wincent, 2011), enhancing SMEs' managers external control of the alliance building process. Therefore, we can anticipate that previous relationships will reduce the uncertainty and will decrease the level of perceived difficulty in the negotiation of the agreement, achieving a positive effect on the intention to develop international alliances. Therefore, we propose:

$H 4 b$ : There is a positive and significant relation between the prior knowledge of a partner and the intention of SMEs' managers to enter into an international alliance. 
Research has highlighted that many decisions such as working on an international project, or start-up require an estimate of probabilities of future events (Houstona et al., 2012; Bracha and Brown, 2012). Under uncertainty, decision-makers tend to be optimistically biased in assessing these probabilities, overestimating the likelihood of favourable future outcomes and underestimating the likelihood of unfavourable future outcomes (Slovic, 2000). Moreover, Shiller (2000) pointed out several psychological factors that affect individuals' beliefs and selfefficacy, and indicated that experience is a moderator of optimistic bias. In this line, research on cognitive entrepreneurship stresses that identification of opportunities varies among entrepreneurs according to their experiences (Wood and Bandura, 1989; Baron, 2004, 2006; Baron and Ensley, 2006). Mitchell et al. (2000) highlight that experienced entrepreneurs tend to have a more realistic perception on business opportunities than novel entrepreneurs because of the experience gained over time. This is why studies suggest that new entrepreneurs will be more likely to overestimate future profitability of potential entrepreneurial opportunities due to a more optimistic perception of obstacles and threats (Gregoire et al., 2010; Groves et al, 2011). Therefore, we propose that when managers become more experience through the years of international activity they become less optimistic about the emergence of potential business opportunities abroad. From the PBC perspective, this will have a negative influence on the internal and external control, which will also negatively affect the intention of developing an international alliance. Taking these ideas into account, we formulate that:

H4c: There is a decreasing relationship between the extent of the international experience of SMEs' managers and the intention to develop an international alliance.

\section{Methods}

\section{Data collection}

In order to test the intention to develop an international alliance, we used a list of 778 Spanish SMEs experienced in international activities, provided by the Spanish Chambers of Commerce, as an initial sampling frame. These companies form a representative sample of the Spanish internationalized SMEs, 653 of which are assigned to industrial activity and 125 to services. Our empirical data were obtained through a mail survey which was performed in two phases. A preliminary survey test was carried out on a small scale in order to test the questionnaire's design, clarity and wording. With this feedback the revised questionnaire was sent to the manager or general director of each of the companies. Data were collected over a period of six months during 2012. Our data collection yielded 220 valid surveys, making an available return rate of 28.3 per cent. Of these, 76.2 per cent are involved in import and export, 
and 23.8 per cent only export. Nearly half of companies cooperate in the development of foreign activities (49.3\%): in non-equity $(77.1 \%)$ and equity agreements $(22.9 \%)$. Cooperation is closely related with the size of the firm; thus while 20.3 per cent of companies with fewer than 20 employees cooperate for the internationalisation, this rises to 58.6 per cent for firms with more than 100 workers. Similarly, more complex figures of cooperation are more common among large companies; thus while 4.9 per cent are joint ventures in the case of companies with fewer than 20 workers, this rises to 29.3 per cent for those with more than 100 employees; in contrast, consortia make up 2.5 per cent in the first case vs. 19 per cent in the second one.

We checked the potential for nonresponse bias by employing t-test and ANOVA analyses (Armstrong and Overton, 1977) comparing the characteristics of the respondents to those of the targeted population. We did not find any significant difference between the characteristics of firms that responded to the survey and those that did not respond. Given that our results may be affected by common-method bias, questionnaire items were arranged so that the dependent variable followed, rather than preceded the independent variables, and we guaranteed response anonymity (Podsakoff et al., 2003); in addition we performed Harman's single-factor test (Harman, 1967) suggesting the absence of common-method bias in our results.

\section{Measures}

\section{Dependent variable}

The intention variable is conceptualised as a perceived dimension (Shapero, 1975; Souitaris et al., 2007; Kibler et al., 2014). In our paper, we follow the original model from Shapero (1975) that proposed only one item to measure the subjects' intent to start a business, and adapted the measurement of that item from Kibler et al. (2015). This type of analysis has been previously used in other empirical research (Krueger, 1993; Krueger, Reilly and Casrud, 2000). We asked the SMEs' managers to what extent they agreed with the following item: "I intend to take steps to start an international alliance in the next 12 months". The intention to develop an international alliance was measured by using a balanced 7-point Likert-type scale, were "1", represented "low agree" and "7"' represented "high agree".

\section{Independent variables}

Ajzen (1991) argued that perceptions will be influenced by previous behavioural outcomes, and relationships between past and future behaviour should be mediated by intentions and PBC. We have exposed in the literature review that intention is affected by the difficulties encountered 
in present and past experiences on alliance building process (in our case with reference to the previous three years). Sparks et al. (1997) point out that the perceived difficulty refers to the perceived ease or difficulty of performing the behaviour in question, and answer the item: "For me to do X would be ... [easy-difficult]".

In the selection of the partner phase, the entrepreneur detected the need to search for partner(s) to implement an international objective, which may be the development of new capacities, the growth or simply the solution of certain shortcomings. Moreover, following Hatfield and Pearce (1994), Das and Teng (1998), Baum et al. (2000), Lu and Beamish (2006), Hitt et al. (2007), and Swoboda et al. (2011), we asked respondents to identify, from a list of actions given in the questionnaire, the degree of perceived difficulty they found at this stage related to: (1) identify the reasons for the international cooperation, (2) the partner selection criteria, (3) the channels used to search for partners, and (4) the firsts contacts. Simplicity in scoring was sought by using a balanced 7-point Likert-type scale, were "1'" represented "low degree" and "7"' represented "high degree".

In the negotiation of the cooperation agreement, the company has already established contact with the partner(s) and has set out the negotiating areas. Based on the spirit of $\mathrm{Lu}$ and Beamish (2006), Manigart et al. (2006), Reuer and Ariño (2007), Li (2013), Swoboda et al. (2011), and Hopp and Lukas (2014), we developed a multi-item scale. The difficulties perceived in the negotiation of the agreement were assessed by asking the respondents to indicate to what extent the following actions were problematic during the negotiation: (1) the design of contract agreement, (2) the negotiation of the contributions of partners and sharing of benefits, (3) the negotiation of the distribution of partner roles and functions, (4) the design of the hierarchical structure and control mechanisms, (5) the definition and formulation of a strategic plan for international cooperation, and (6) the relation with the partner(s). We used 7-point Likert scale, were " 1 " represented "low degree" and " 7 " represented "high degree".

According to Gulati (2000) and Reuer and Ariño (2007), the experience of the company in the development of international agreements can be measured by the firm's familiarity about the problems of cooperation. Thus, we operationalized this knowledge with reference to the previous three years by a two-item scale that measures: (1) the experience in internationalization agreements, (2) the experience with the same partners. Respondents evaluate the extent of its experience in relation to the statement given; where 1 represents the lowest level, and 7 represent the highest level. 
Age and antiquity in international activities was measured as the natural log of the number of months that the SME has operated abroad (Hagedoorn and Narula, 1996; Lu and Beamish, 2001, 2006).

\section{Control variables}

Testing the hypotheses required that we control for the possible effects of other variables to account for relevant effects that could influence the impact of the independent variables, and to provide new empirical evidence that could shed some light on inhibiting factors of SMEs in international collaboration.

Specifically we have considered four groups of control variables (see Table 1). The first one makes reference to the SME; the second one to the entrepreneur; the third one the type of agreement; the four one to the environmental characteristics. In the case of the SME, based on Hutchinson et al (2009), Bell et al. (2005), and Ruzzier et al. (2006), we have included the following control variables: (1) size, (2) international turnover, (3) inter-sectorial nature of firms, and (4) manufacturing or service. Regarding the entrepreneur, following Manolova et al. (2002), we controlled for: (1) international business skills, and (2) international orientation. As regards the international cooperation agreement, following Hagedoorn and Narula (1996); Dhanarj and Beamish (2004), and Wang and Nicholas (2005), we have included the following control variables to classify the type of cooperation agreement according to the implication degree of partner: (1) equity, and (2) non-equity international agreement. Based on Lu and Beamish (2001, 2006), we controlled for the environmental characteristics, measuring (1) the international networks, and (2) the geographical areas.

-Insert Table 1 about here

\section{Analysis and Results}

Table 2 presents the descriptive statistics and Pearson correlation coefficients for all variables used in this study and Table 3 reports OLS regression results.

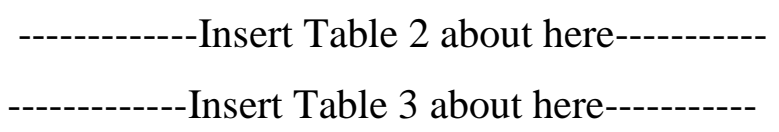

Table 3 presents the results of our estimation. We estimated eight different model specifications. Model 1 contains the dependent variable (intention) and the nine control variables. Model 2a captures the dependent variable as a function of searching and selection process, plus control variables; Model $2 \mathrm{~b}$ includes searching and selection significant variables, with control variables. 
Model 3a captures the dependent variable as a function of the negotiation process, and includes control variables; Model 3b includes negotiation significant variables, with control variables. Model 4 captures the dependent variable as a function of selection and negotiation significant variables, with control variables. Model 5 captures the dependent variable as a function of experience variables, and control variables. Models 6 captures the dependent variable as a function of searching and selection, negotiation, experience variables, years of internationalization, and variables of control. Model fits are acceptable with significant chisquare values ( $\mathrm{p}<0.01$ ) and $\mathrm{R}^{2}$ values ranging from 0.302 to 0.511 for all specifications.

Our results show that the intention of SMEs' managers to develop an international alliance is generally high, as it is observed by the average value of the response that is close to five (see Table 2). The intention seems to be higher the higher the company size and the higher the international activity and international contacts; this however is not significant, as evidenced the MANOVA analysis performed. Sectoral and geographical variables do not have an impact on the entrepreneurial intention. Similarly, we observe that the type of contractual alliance (equity and non-equity alliance) has no effect on the intention, contrary to what some studies point out when note that the type of partnership is important for the formation and development of alliances (Globerman and Nielsen, 2007). These results support the arguments from D'Este et al. (2012), which point out the need to differentiate between studies that address the importance of barriers and those that consider the dissuasive effect of them.

Regarding the effect of the independent variables, for both selection and negotiation, SMEs' managers perception of difficulty is similar and high (the difficulty level perceived is greater than 4 , with the exception of the negotiation of the strategic alliance plan that is close to 3 (see Table 2)). This last result confirms previous literature which highlights that one of the problems for the alliance success is the lack of an adequate strategic plan, which is due to the low degree of involvement of the managers (Hagedoorn et al., 2000; Reuer and Ariño, 2007). Unlike the intention, in the independent variables, we did not observe any significant bias with the characteristics of the SME.

From the results of Model 2, we find that not all tasks in the selection process have a significant negative relationship with the intention. Thus, we find that the definition of the partner profile $(\beta=-0378, \mathrm{p}<0.05)$ and the selection of the search channels $(\beta=-0.125, \mathrm{p}<0.10)$ have a degree of difficulty that significantly impact on the intention to enter an international cooperation agreement. Similarly in Model 3, we find that the preparation of the contract $(\beta=-$ 0203, $\mathrm{p}<0.05)$, the contribution of partners $(B=-0112, \mathrm{p}<0.10)$, the development of a plan $(B=$ $-0155, \mathrm{p}<0.10)$ and the relation with the partners $(B=-0192, \mathrm{p}<0.10)$ have a degree of difficulty 
significantly impacts the intention to international cooperation. These findings support Hypotheses 1 and 2. Furthermore, they provide empirical evidence of the inhibition effect that the difficulties encountered in negotiation and selection have on international cooperation agreements, explaining why institutions devote large efforts to the facilitation of these tasks (Lu and Beamish, 2006; Raymond and St-Pierre, 2013).

To corroborate or refute Hypothesis 3, following Liu et al. (2009), we examined through the proportion of variance explained whether partner selection has a greater effect than partner negotiation in the inhibition of international cooperation. Thus, taking the partner selection variable to explain Hypothesis 3, we obtain $\operatorname{adj} \Delta \mathrm{R}^{2}$ as follows from the regression results of Model 4 and Model 3b: $\operatorname{adj} \Delta R^{2}{ }_{\text {Model4-Model3b }}=\operatorname{adj}^{2}{ }_{\text {Model4- }} \operatorname{adj}^{2}{ }_{\text {Model3b }}=0.468-0.383=0.085$. Here $\operatorname{adj} \Delta \mathrm{R}^{2}$ Model4-Model3b represents the proportion of the variance of intention variable that can be explained by the partner selection variable. Similarly, $\operatorname{adj} \Delta R^{2}{ }_{\text {Model4-Model } 2 b}=\operatorname{adj} R^{2}{ }_{\text {Model } 4}{ }^{-}$ $\operatorname{adj} \mathrm{R}_{\text {Model2b }}^{2}=0.468-0.399=0.069$, represents the proportion of the variance of intention variable explained by negotiation variable. Since $\operatorname{adj} \Delta R^{2}{ }_{\text {Model4-Model3b }}>\operatorname{adj} \Delta R^{2}$ Model4-Model2b, we can conclude that partner selection is more forceful as an inhibition factor on the intention to develop an international cooperation agreement. This finding supports Hypothesis 3. In the existing literature, researchers have contended that the low implication of the partners, as a result of a not appropriate selection, is one of the main problems of cooperation, which is reflected in the lack of definition of agreements (Wolff and Pett, 2000; Lu and Beamish, 2006; and Ruzzier et al., 2006; Alegre et al., 2013).

Testing Hypotheses $4 \mathrm{a}$ and $4 \mathrm{~b}$, we observe that the variable experience in international cooperation $(\beta=0.205, \mathrm{p}<0.05)$ as well as previous experience with a partner $(\beta=0.307, \mathrm{p}<$ 0.05) have a positive and significant effect on the intention to develop international cooperation agreements. Our findings provide empirical evidence that the experience and trust generated with known partners motivate the development of agreements (Bierly and Gallagher, 2007; Fink et al., 2008; Pathak and Zibarras, 2010).

To test Hypothesis 4c, we have combined experience over the years with international activity in order to verify if the experience affects the intention of developing an international cooperation agreement. Our results are not significant. However, we performed an additional analysis, dividing the sample into three stages of experience following the Global Entrepreneurship Monitor (less than one year; between 1 and five years; and more than five years of experience); the results showed a higher marginal effect less experienced in entrepreneurs, and stabilized values in the following two stages of experience. Therefore, our 
hypothesis is partially confirmed, supporting the assumption of the importance of optimism as mediator of the relationship between experience and the intention to develop a new venture.

\section{Discussion and Conclusion}

The overall aim of this study was to investigate the inhibiting factors of alliance building in SMEs' internationalisation. In doing so, this paper has addressed the decisional process that leads to enter an international alliance from managers' perspective. We contribute to the literature which is largely composed of studies that focus on success drivers in the internationalisation of SMEs- by showing how perceived difficulties in the internationalisation alliance building process affect SMEs managers' the cooperation intention. As we pointed out, a great deal of literature has investigated the factors that affect the development and the failure of alliances. To a lesser extent, literature has explored the ex-ante factors that influence the intention of pursuing an international alliance, but there is a gap in how alliance building affects the intention of international venture. Our research highlights the importance of this ex-ante phase and may help to explain the reasons of the low implementation of this strategic path in the internationalisation of SMEs. From the PBC perspective, we support that both selection and negotiation have a bearing on the intention of SMEs' internationalization through a cooperation agreement. The findings of this study reveal that the intention to develop an international alliance is moderated by the experience of the manager. We posit that managers' intention to make an international alliance is a balance between inhibiting factors (alliance building process), and moderating factors (experience) that affect the degree of managers' internal and external control of the alliance building process. The empirical evidence of this study supports the conclusion that the perceived difficulty in the alliance building process has a negative effect on the intention to develop an international alliance. Our results also highlight the importance of developing both stages -searching and selection, and negotiation-, although the difficulty in selecting the partner has a bigger weight on the involvement in an international collaboration. This finding is particularly interesting in the case of Spanish SMEs whose main barrier to face an international alliance is the perception that its start-up is a very complex and long-winded process. Moreover, the results show how appropriate mixes of experience and preparation time have a positive effect on the development of SMEs' international alliances. Given the role of government support organizations in addressing the barriers to SME internationalization, it is likewise argued that the results of this study have important implications for policy makers as managers' inhibiting factors in international alliances determine their future engagement in international business activities. 
From the manager's point of view, we would like to highlight the importance of considering the ex-ante process of the international alliance as an "integral process". We have shown the importance of the selection task with respect to the negotiation in the intention to develop the agreement. However, this should not minimize the role of negotiation. As noted by Gulati (2000) and Reurer and Ariño (2007), negotiation is key to project success. Thus, negotiation serves to initiate the relationship and enable partners to get to know each other, as well as to detect whether complicity exists between them. This question is of utmost importance to ensure that commitment and confidence, key pieces in cooperation agreements, constitute the basis of their relationship (Deeds and Hill, 1998; BarNir and Smith, 2002). The evidence suggests that managers should pay attention to variables such as coordination, conflict of interests, as well as financial weakness and the accurate definition of objectives, to ensure the adequate development of cooperation agreements. The flexibility and low level of commitment required initially by international cooperation may mean that relationships are not built on suitable planned foundations (objectives and strategic plans), which is the opposite of what occurs when firms take decisions regarding growth, mergers or takeovers. Accordingly, the relationships built by planning suitable organization, information and control systems could prevent the appearance of conflictive situations.

Theoretical, methodological, and geographical limitations suggest a variety of future research directions. Theoretically, we have emphasized the role of managers' intention in the ex-ante dimensions of alliance building to complement the wealth of inter firm cooperation research that often draws on internal features of SME and on external and facilitating factors. It may be useful for future research to assess the relative weight of these different theoretical factors in one integrative study.

Methodologically, although several figures of cooperation have been identified in the companies of our sample, we did not analyse particular alliance forms: joint ventures, licensing, distribution/production agreements that may differ in terms of their specific cooperation building tasks, as well as the values of their time dimensions. Replications of our study in the different cooperative interfirm relationships are needed to establish the external validity of our findings. As in many other large-sample surveys on interfirm cooperation, we too only had a single informant in the firm. We should acknowledge the possible biases involved in questioning only a single informant, and that also it would be beneficial obtain the assessment of all partners in each relationship. 
Geographically, limiting our study to Spain, leaves open the question of the generalizability of our results. There may be differences across countries and institutional environments with respect to the internationalisation of small firms. This issue needs to be explored in countries in which alliances and cooperation for internationalisation may be more important. It remains to be seen in future research whether our Spain-based findings can be generalised to other countries.

\section{References}

Ajzen, I. 1991. The theory of planned behaviour. Organizational Behavior and Human Decision Processes, 50, 179-211.

Ajzen, I. 2002. Perceived Behavioral Control, Self-Efficacy, Locus of Control, and the Theory of Planned Behavior. Journal of Applied Social Psychology 32, 1-20.

Ajzen. I. and Fishbein, M. 1977. Attitude-behavior relationships: A theoretical analysis and review of empirical research. Psychological Bulletin 84, 888-918.

Ajzen, I., and Madden, T. J. 1986. Prediction of goal directed behavior: Attitudes, intentions and perceived behavioural control. Journal of Experimental Social Psychology, 22, 453-474.

Alegre, J, Sengupta, K. and Lapiedra, R. 2013. Knowledge management and innovation performance in a high-tech SMEs industry. International Small Business Journal 31(4), 454470.

Al-Laham, A., Amburgey, T. and Bates, K. 2008. The Dynamics of Research Alliances: Examining the Effect of Alliance Experience and Partner Characteristics on the Speed of Alliance Entry in the Biotech Industry. British Journal of Management 19(4), 343-364.

Armstrong, J. S., and Overton, T. S. 1977. Estimating nonresponse bias in mail surveys. Journal of Marketing Research, XIV, 396-402.

Audretsch, D.B. 2009. The entrepreneurial society. Journal of Technology Transfer, 34, 245254.

Bandura, A. 1977. Self-efficacy: toward a unifying theory of behavioural change. Psychological Review, 84(2), 191-215.

Bandura, A., 1986. Social foundations of thought and action: A social cognitive theory. Englewood Cliffs, NJ: Prentice-Hall.

BarNir, A. and Smith, K.A. 2002. Interfirm Alliances in the Small Business: The Role of Social Networks. Journal of Small Business Management, 40(3), 219-32.

Baron R., 1998. Cognitive mechanisms in entrepreneurship: why and when entrepreneurs think differently than other people. Journal of Business Venturing, 13, 275-294. 
Baron R., 2004. The cognitive perspective: a valuable tool for answering entrepreneurship's basic "why" questions. Journal of Business Venturing, 19, 221-239.

Baron R., 2006. Opportunity recognition as pattern recognition: how entrepreneurs "connect the dots" to identify new business opportunities. Academy of Management Perspectives, 20, 104119.

Baron R. and Ensley, M., 2006. Opportunity recognition as the detection of meaningful patterns: evidence from comparisons of novice and experienced entrepreneurs. Management Science, $52,1331-1344$.

Baum, J.A.C., Calabrese, T. and Silverman, B.S. 2000. Don't Go It Alone: Alliance Network Composition and Startups' Performance in Canadian Biotechnology. Strategic Management Journal 21(3), 267-294.

Bell, J. 1995. The Internationalisation of Small Computer Software Firms- A Further Challenge to Stage Theories. European Journal of Marketing 29(8), 60-75.

Bell, J., Crick, D. and Young, S. 2004. Small Firm Internationalisation and Business Strategy: An Exploratory Study of 'Knowledge-Intensive' and 'Traditional' Manufacturing Firms in the UK. International Small Business Journal 22(1), 23-56.

Bell, J., McNaughton, R. and Young S. 2001. Born-Again Global' Firms: An Extension to the 'Born Global' Phenomenon. Journal of International Management 7(3), 173-189.

Bierly III, P. E., and Gallagher, S. 2007. Explaining alliance partner selection: fit, trust and strategic expediency. Long Range Planning, 40(2), 134-153.

Bird, B. 1989. Entrepreneurial behavior. Glenview, IL: Scott, Foresman and Company.

Bracha, A. and Brown, D.J. 2012. Affective decision making: A theory of optimism bias. Games and Economic Behavior 75, 67-80.

Burgel, O., and Murray, G.C. 2000. The International Market Entry Choices of Star-Up Companies in High-Technology Industries. Journal of International Marketing, 8(2), 33-62.

Carpenter, M. A., Geletkanycz, M. A., and Sanders, W. G. 2004. Upper echelons research revisited: Antecedents, elements, and consequences of top management team composition. Journal of Management, 30(6), 749-778.

Carsrud, A., Brännback, M., 2011. Entrepreneurial motivations: what do we still need to know? Journal of Small Business Management 49, 9-26.

Chrisman, J. J., McMullan, E., and Hall, J. 2005. The influence of guided preparation on the long-term performance of new ventures. Journal of Business Venturing, 20(6), 769-791. 
Chwoka, A., Raith, M. G. 2012. The Value of Business Planning Before Start - up - A Decision - Theoretical Perspective. Journal of Business Venturing, 27, 385-399.

Cohen, W.M. and D.A. Levinthal 1990. Absorptive capacity: A new perspective on learning and innovation. Administrative Science Quarterly, 35, 128-152.

Conner, M. and Armitage, C.J. 1998. Extending the theory of planned behavior: A review and avenues for further research. Journal of Applied Social Psychology 28, 1429-1436.

Consejo Superior de Camaras 2007. Internacionalización de la Empresa Española. Cooperación empresarial e inversión exterior. Ed. Cámaras de Comercio.

D’Este, P., Iammarino, S., Savona, M., and von Tunzelmann, N. 2012. What hampers innovation? Revealed barriers versus deterring barriers. Research Policy, 41(2), 482-488.

Das, T. and Teng, B. 1998. Between trust and control: developing confidence in partner cooperation in alliances. Academy of Management Review, 23, 49-521.

Das, T. and Teng, B. 2000. Instabilities of Strategic Alliances: An Internal Tensions Perspective Organization Science, 11(1), 77-101.

Deeds, D. L. and Hill, C.W.L. 1998. And Examination of Opportunistic Action Within Research Alliances: Evidence from the Biotechnology Industry. Journal of Business Venturing, 11(1), 45-56.

Dhanaraj, Ch. and Beamish, P.W. 2004. Effect of Equity Ownership on the Survival of International Joint Ventures. Strategic Management Journal, 25(3), 295-305.

Dwyer, F.R., Schurr, P.H., and Oh, S. 1987. Developing buyer - seller relationships.

Journal of Marketing, 51(2), 11 - 27.

Fernández, Z.and Nieto, M.J. 2006. Impact of ownership on the international involvement of SMEs. Journal of International Business Studies 37, 340-351.

Fink, M., Harms, R. and Kraus, S. 2008. Cooperative internationalization of SMEs: Self commitment as a success factor for international entrepreneurship. European Management Journal, 26, 429-440.

Finkelstein, S., and Hambrick, D.C. 1996. Strategic leadership: Top executives and their effects on organizations. St. Paul, MN: West.

Geringer J.M. (1991). Strategic Determinants of Partner Selection Criteria in International Joint Ventures. Journal of International Business Studies, 22(1), 41-62.

Geringer J.M. and L. Hebert 1989. Control and Performance of International Joint Ventures. Journal of International Business Studies, 17(2), 235-254. 
Globerman, S. and Nielsen, B.B. 2007. Equity versus non-equity international strategic alliances involving Danish firms: An empirical investigation of the relative importance of partner and host country determinants. Journal of International Management, 13(4), 449-471.

Grant, R., Bade-Fuller, C.A., 2004. A knowledge accessing theory of strategic alliances. Journal of Management Studies, 41(1), 61-84.

Grégoire, D., Shepherd, D. and Lambert, L. 2010. Measuring Opportunity-Recognition Beliefs: Illustrating and Validating an Experimental Approach. Organizational Research Methods 13, 114-145.

Groves, K., Vance, C., and Choi, D. 2011. Examining entrepreneurial cognition: an occupational analysis of balanced linear and nonlinear thinking and entrepreneurship success. Journal of Small Business Management 49, 438-466.

Gulati R. 1998. Alliances and Networks. Strategic Management Journal, 19(4), 293-317.

Gulati R., Nohria N. and Zaheer A. 2000. Strategic Networks. Strategic Management Journal, 21(3), 203-215.

Gulati, R. 2000. Strategic Networks. Strategic Management Journal 21 (3), 203-15.

Gulati, R. (2008). Review of The Resource Characteristics of Strategic Alliances. Academy Management Review, 33(2), 553-557.

Haahti, A., Madupu, V., Yavas, U. and Babakus, E. 2005. Cooperative strategy, knowledge intensity and export performance of small and medium sized enterprises. Journal of World Business, 40, 124-138.

Hagedoorn, J. and Narula, R. 1996. Choosing organizational modes of strategic technology partnering: international and sectoral differences. Journal of International Business Studies, $27,265-284$.

Hagedoorn, J., Link, A. and Vornotas, N. 2000. Research partnerships. Research Policy 29, 567586.

Hagedoorn, J., N. Roijakkers and H. Van Kranenburg 2006. Inter-Firm R\&D Networks: the Importance of Strategic Network Capabilities for High-Tech Partnership Formation. British Journal of Management 17(1), 39-53.

Hambrick, D.C., and Mason, P.A. 1984. Upper echelons: The organization as a reflection of its top managers. Academy of Management Review 9(2), 193 - 206.

Harman H.H. (1967). Modern Factor Analysis. University of Chicago Press, Chicago.

Hatfield, L. Pearce II, J.A. 1994. Goal achievement and satisfaction of joint venture partners. Journal of Business Venturing, 9(5), 423-449. 
Hernan, R., Marin, P. and Siotis, G. 2003. An empirical evaluation of the determinants of research joint venture formation. Journal of Industrial Economics, LI, 75-89.

Hills, G. E., Shrader, R. C., and Lumpkin, G. T. 1999. Opportunity recognition as a creative process. In R. D. Reynolds, W. D. Bygrave, S. Manigart, C. M. Mason, G. D. Meyer, H. J. Sapienza, and K. G. Shaver (Eds.), Frontiers of entrepreneurship research, 567-591. Waltham, MA: P \& R Publication Inc.

Hitt, M., Zhang, A. Li, H. 2007. R\&D Intensity and IJV Performance in an Emerging Market: Moderating Effects of Market Focus and Ownership Structure. Journal of International Business Studies, 38, 944-60.

Hmieleski, K. M., \& Baron, R. A. 2009. Entrepreneurs' optimism and new venture performance: A social cognitive perspective. Academy of management Journal, 52(3), 473-488.

Hoffmann, W.H. and Schaper-Rinkel, W. 2001. Acquire or Ally?-A Strategy Framework for Deciding between Acquisition and Cooperation. Management International Review, 41(2), 131-59.

Holmberg, S.R. and Cummings, J.L. 2009. Building Successful Strategic Alliances Strategic Process and Analytical Tool for Selecting Partner Industries and Firms. Long Range Planning 42, 164-193.

Hopp, C. and Lukas, C. 2014. A Signaling Perspective on Partner Selection in Venture Capital Syndicates. Entrepreneurship Theory and Practice 38(3), 635-670.

Houstona, A. Trimmera, P., Fawcetta, W., Higginsona, A., Marshall, J. and McNamara, J. 2012. Is optimism optimal? Functional causes of apparent behavioural biases. Behavioural Processes 89, 172- 178.

Hutchinson K. and Fleck E. and Lloyd-Reason L. 2009. An investigation into the initial barriers to internationalization Evidence from small UK retailers, Journal of Small Business and Enterprise Development 16(4), 544-568.

Inkpen A.C., Beamish, P.W. 1997. Knowledge, bargaining power, and the instability of international joint ventures. Academy of Management Review 22(1), 177-202.

Julien, P. A., and Ramangalahy, C. 2003. Competitive strategy and performance of exporting SMEs: an empirical investigation of the impact of their export information search and competencies. Entrepreneurship Theory and Practice, 27(3), 227-245.

Kalantaridis, Ch. 2004. Internationalization, Strategic Behavior, and the Small Firm: A Comparative Investigation. Journal of Small Business Management 42(3), 245-262. 
Kang, H., Hahn, M., Fortin, D. R., Hyun, Y. J., and Eom, Y. 2006. Effects of perceived behavioral control on the consumer usage intention of e-coupons. Psychology and Marketing, 23(10), 841 .

Katz, J., and Gartner, W. B. 1988. Properties of emerging organizations. Academy of Management Review 13(3), 429-441.

Kibler, E., Kautonen, T. and Fink M. 2014. Regional Social Legitimacy of Entrepreneurship: Implications for Entrepreneurial Intention and Start-up Behaviour, Regional Studies, 48:6, 995-1015.

Kirby, D. A., and Kaiser, S. 2003. Joint ventures as an internationalisation strategy for SMEs. Small Business Economics, 21(3), 229-242.

Krueger, N. and Brazeal, D. 1994. Entrepreneurial Potential and Potential Entrepreneurs. Entrepreneurship Theory and Practice, 18(3), 91-104.

Larson, A. 1992. Network dyads in entrepreneurial settings: A study of the governance of exchange relationships. Administrative Science Quarterly, 37, 76 - 104.

Li, D. 2013. Multilateral R\&D alliances by new ventures. Journal of Business Venturing, 28(2), 241-260.

Liñán, F., and Chen, Y. 2009. Development and cross-cultural application of a specific instrument to measure entrepreneurial intentions. Entrepreneurship Theory and Practice 33, 593-617.

Liu Y., Luo, Y. and Liu, T. 2009. Governing Buyer-Supplier Relationships through Transactional and Relational Mechanism: Evidence from China. Journal of Operations Management, 27(4), 294-309.

Lu, J. and Beamish, P. W. 2006. Partnering Strategies and Performance of SMEs' International Joint Ventures. Journal of Business Venturing, 21(4), 461-86.

Lu, J.W. and Beamish, P.W. 2001. The Internationalization and Performance of SMEs. Strategic Management Journal 22(6-7), 565-586.

Majocchi, A. and Zucchella, A. 2003. Internationalization and Performance: Findings from a Set of Italian SMEs. International Small Business Journal 21(2), 249-268.

Manolova, T., Brush, C., Edelman, L. and Greene, P. 2002. Internationalization of Small Firms. Personal Factors Revisited. International Small Business Journal 20(1), 9-31.

McDougall, P.P. and Oviatt, B.M. 2000. International Entrepreneurship: The Intersection of Two Research Paths. Academy of Management Journal 43(5), 902-906. 
McDougall, P.P., and Oviatt, B.M. 1999. International Entrepreneurship Literature in the 1990s and Directions for Future Research. In D.L. Sexton, and Smilor, R. W. (eds.) Entrepreneurship 2000, Chicago, IL.: Upstart Publishing, 291-320.

McDougall, P.P., Shane, S. and Oviatt, B.M. 1994. Explaining the Formation of International New Ventures: The Limits of Theories from International Business Research. Journal of Business Venturing 9(6), 469-87.

Mitchell, R., Smith, B., Seawright, K., Morse, E., 2000. Cross-cultural cognitions and the venture creation decision. Academy of Management Journal, 43, 974-993.

Mohr J. and R. Spekman 1994. Characteristics of Partnership Success: Partnership Attributes, Communication, Behaviour, and Conflict Resolution Techniques. Strategic Management Journal, 15(2), 135-152.

Observatory of European SMEs, 2010. Internationalization of SMEs. European Commision.

Osborn, R.N., and Hagedoorn, J. 1997. The institutionalization and evolutionary dynamics of interorganizational alliances and networks. Academy of Management Journal, 40(2), 261 278.

Pathak, S.B. and Zibarras, L. 2010. Advancing selection in an SME: Is best practice methodology applicable? International Small Business Journal 28(3), 258-273.

Podsakoff, P.M., S.B. MacKenzie, J.Y. Lee and N.P. Podsakoff 2003. Common Method Biases in Behavioral Research: A Critical Review of the Literature and Recommended Remedies. Journal of Applied Psychology 88(5), 879-903.

Poppo, L. and Zenger T. 2002. Do Formal Contracts and Relational Governance Function as Substitutes or Complements? Strategic Management Journal, 23(8), 707-725.

Raymond, L. and St-Pierre, J. 2013. Strategic capability configurations for the internationalization of SMEs: A study in equifinality. International Small Business Journal $31(1), 82-102$.

Reuer, J. and A. Ariño 2007. Strategic Alliance Contracts: Dimensions and Determinants of Contractual Complexity. Strategic Management Journal, 28(3), 313-330.

Ruzzier, M., Kranj, A., Hisrich, R. and Antoncic B. 2006. SME internationalization research: past, present, and future. Journal of Small Business and Enterprise Development 13(4), 476497.

Shapero, A. 1975. The displaced, uncomfortable entrepreneur. Psychology Today, 83-88.

Shapero, A., and Sokol, L. 1982. The social dimensions of entrepreneurship. In Kent, C., Sexton, D., and Vesper, K., (eds.), Encyclopedia of Entrepreneurship, Prentice Hall, Englewood Cliffs, NJ, 72-90. 
Shrader, R.C. 2001. Collaboration and Performance in Foreign Markets: The Case of Young, High-Technology Manufacturing Firms. Academy of Management Journal 44(1), 45-60.

Shiller, Robert J. 2000. Irrational Exuberance. Princeton: Princeton University Press, $1^{\text {st }}$ ed.

Slovic, Paul. 2000. The Perception of Risk. London: Earthscan Publications Ltd.

Soutaris V., Zerbinati S. and Al-Laham A. (2007) Do entrepreneurship programmes raise entrepreneurial intention of science and engineering students? The effect of learning, inspiration and resources, Journal of Business Venturing 22, 566-591.

Sparks, P., Guthrie, C. A., and Shepherd, R. 1997. The Dimensional Structure of the Perceived Behavioral Control Construct1. Journal of Applied Social Psychology 27(5), 418-438.

Spekman, R.E., Forbes, T.M., Isabella, L.A., and Macavoy, T.C. 1998. Alliance management: A view from the past and a look to the future. Journal of Management Studies, 35(6), $747-772$.

Swoboda, S., Meierer, M, Foscht, T and Morschett, D. 2011. International SME Alliances: The Impact of Alliance Building and Configurational Fit on Success. Long Range Planning 44, 271-288.

Thompson, E. R. 2009. Individual entrepreneurial intent: construct clarification and development of an internationally reliable metric. Entrepreneurship Theory and Practice, 33(3), 669-649.

Thorgren S. and Wincent, J. 2011. Interorganizational Trust: Origins, Dysfunctions and Regulation of Rigidities. British Journal of Management 22(1,) 21-41.

Wang, Y. and Nicholas, S. 2005. Knowledge Transfer, Replication and Learning in Non-Equity Alliances: Operating Joint ventures in China. Management International Review, 45, 99-118.

Williamson, O.E. 1985. The economic institutions of capitalism. The Free Press, New York.

Williamson, O.E. 2002. The Theory of the Firm as Governance Structure: From Choice to Contract. Journal of Economic Perspectives, 16(3), 171-196.

Winch, G.W. and Bianchi, C. 2006. Drivers and dynamic processes for SME's going global. Journal of Small Business and Enterprise Development, 13(1), 73-88.

White, K. M., Terry, D. J., and Hogg, M. A. 1994. Safer sex behavior: The role of attitudes, norms, and control factors. Journal of Applied Social Psychology 24, 2164-2192.

Wolff, J. A. and Pett, T.L. 2000. Internationalization of Small Firms: An Examination of Export Competitive Patterns, Firm Size, and Export Performance. Journal of Small Business Management, 38(2), 34-47. 
Wood, R. and Bandura, A. 1989. Social cognitive theory of organizational management. Academy of Management Review 14, 361-384.

Wooldridge, J. 2009. Introductory Econometrics. South Western College, NY.

Zhou, X., Li, Q., Zhao, W. and Cai, H., 2003. Embeddedness and contractual relationships in China's transition economy. American Sociological Review 68 (1), 75-102. 
Figure 1: Conceptual model.

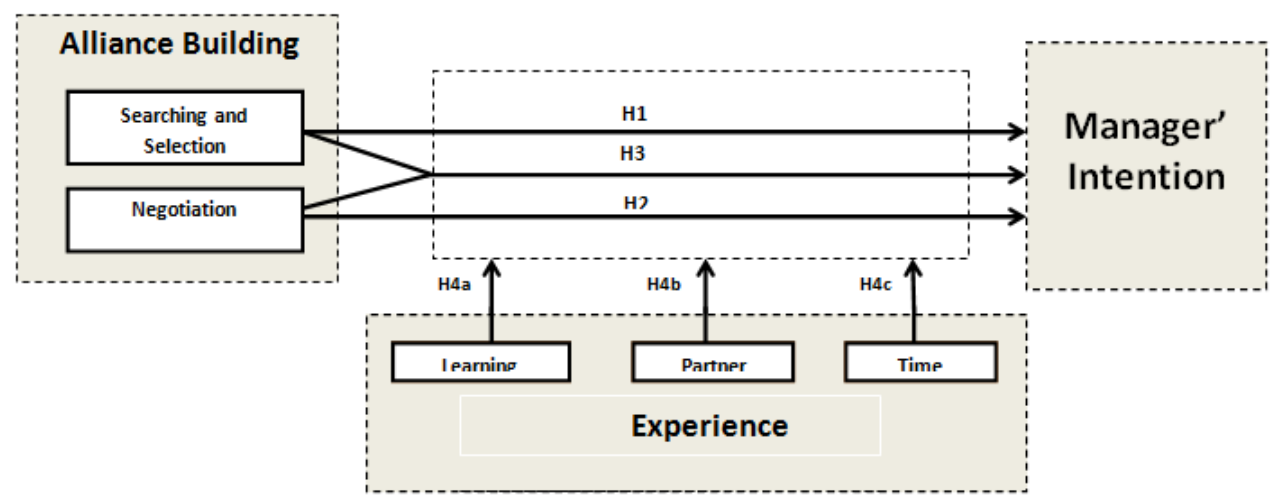

Table 1. Variables and Measures

\begin{tabular}{l}
\hline Variables and Measures \\
\hline Depend Variable: \\
Measuring Intentions in the next 12 months. \\
Independent Variables: \\
Selection of the partner measures (Hypothesis 1$)$ \\
1. Difficult to identification of reasons for carrying out an international \\
cooperation agreement (REASONS).
\end{tabular}
cooperation agreement (REASONS).
Preparing the initial dossier;

0.716

0.634

Presentation of the promoter;

Description of requirements of the partner;

Pre-defining an organizational structure for the development of a cooperation agreement.

2. Difficult to establish of the partner selection criteria (CRITERIA).

Managerial skills;

Foreign market power;

International marketing expertise;

Foreign partners' complementary technological and managerial.

3. Difficult to define the channels to search for partners (CHANNELS)

4. Difficult to select the partner and first contacts (CONTACTS).

0.650

0.499

0.551

0.637

0.494

0.601

0.389
Technological capability;

Cronbach's VIF
Alpha

0.71

1.736

0.73

1.696

Negotiation of agreement measures (Hypothesis 2)

5. Difficult in the design of contract agreement (CONTRACT).

Preparation and definition;

Structure of contract;

Contents of contract.

0.609

0.624

0.711

sharing of benefices (CONTRIBUTION).

Contribution partners

Payoff.

7. Difficult in the negotiation of the distribution of partner roles and functions (ROLES).

Distribution roles;

Distribution functions;

Distribution of tasks.

8. Difficult in the design of the hierarchical structure and control mechanisms (GOVERNANCE).

Organization agreement;

Power distribution;

Control mechanisms.

0.616 
(Hypothesis 4b).

Measuring age and antiquity in international activities (YEARS),

(Hypothesis 4c).

\section{Control Variables:}

\section{From the Entrepreneur}

International Skills

International work experience;

Personal networks and relationships abroad; $\quad 0.624$

Marketing expertise; $\quad 0.732$

International business education; $\quad 0.701$

Expertise in technology and communication. $\quad 0.662$

International Orientation

Extent of travel;

0.528

Time lived abroad;

0.660

Level of Studies;

0.499

Employment abroad

0.586

From the Environmental characteristics

International networks.

Geographical areas (Europe; Latin America).

Size.

International turnover. 

Table 2. Correlation matrix

\begin{tabular}{|c|c|c|c|c|c|c|c|c|c|c|c|c|c|c|c|c|c|c|c|c|c|c|c|c|}
\hline & Mean & $\mathrm{St}$ & 1 & 2 & 3 & 4 & 5 & 6 & 7 & 8 & 9 & 10 & 11 & 12 & 13 & 14 & 15 & 16 & 17 & 18 & 19 & 20 & 21 & 22 \\
\hline 1. Selection (Reasons) & 4.5 & 1.83 & & & & & & & & & & & & & & & & & & & & & & \\
\hline 2. Selection (Criteria) & 5.7 & 0.77 & $.339^{* * *}$ & & & & & & & & & & & & & & & & & & & & & \\
\hline 3. Selection (Channels) & 5.2 & 1.01 & $.125^{*}$ & $.224 *$ & & & & & & & & & & & & & & & & & & & & \\
\hline 4. Selection (Contacts) & 4.1 & 1.29 & $.117^{*}$ & $.192 *$ & $.378^{*}$ & & & & & & & & & & & & & & & & & & & \\
\hline 5. Negotiation (Contract) & 5.6 & 1.19 & .156 & .028 & $.119^{*}$ & $.201 *$ & & & & & & & & & & & & & & & & & & \\
\hline 6. Negotiation(Contribution) & 5.9 & 1.33 & .071 & .085 & $.123 *$ & $.239 *$ & $.330 * *$ & & & & & & & & & & & & & & & & & \\
\hline 7. Negotiation (Roles) & 4.7 & 0.82 & $.178^{*}$ & .117 & $.173 *$ & $.198 *$ & $.381^{* *}$ & $.240^{*}$ & & & & & & & & & & & & & & & & \\
\hline 8. Negotiation (Governance) & 4.8 & 0.90 & $.133^{*}$ & $.110^{*}$ & .061 & $.218^{*}$ & $.375^{* *}$ & $.297 *$ & $.138^{*}$ & & & & & & & & & & & & & & & \\
\hline 9. Negotiation (Plan) & 3.1 & 1.65 & $.278^{* * *}$ & .090 & .028 & $.139 *$ & $.301 * *$ & $.258^{*}$ & $.304 * *$ & $.182 *$ & & & & & & & & & & & & & & \\
\hline 10. Negotiation (Relation) & 4.5 & 1.23 & .092 & .055 & $.210^{* *}$ & $.176^{*}$ & $.294 *$ & $.170^{*}$ & $.301 * *$ & $.112 *$ & $.166^{*}$ & & & & & & & & & & & & & \\
\hline 11. Experience (Cooperation) & 5.3 & 1.58 & $-.194 *$ & $-.203^{* *}$ & $-.325 * *$ & $-.177 *$ & $-.227 *$ & $-.231 *$ & $-.198 *$ & $-.180 *$ & $-.247^{*}$ & $-.299 * *$ & & & & & & & & & & & & \\
\hline 12. Experience (Partner) & 6.0 & 0.55 & $-.133^{*}$ & -.045 & $-.183^{*}$ & $-.317 * *$ & $-.390^{* *}$ & $-.294 * *$ & $-.110 *$ & $-.112 *$ & $-.310^{* * *}$ & $-.381 * *$ & $.451^{* *}$ & & & & & & & & & & & \\
\hline 13. Years & 7.3 & 3.9 & -.083 & -.051 & $-.104 *$ & -.027 & -.068 & -.045 & -.039 & $-.138 *$ & -.036 & -.022 & $.235^{*}$ & $.199 *$ & & & & & & & & & & \\
\hline 14. International Skills & 5.4 & 0.48 & -.043 & -.007 & -.025 & .045 & -.076 & -.002 & -.078 & -.055 & -.037 & -.091 & $.220^{*}$ & $.205 *$ & $.194 *$ & & & & & & & & & \\
\hline 15. International Orientation & 4.9 & 0.53 & $-.110 *$ & $-.124 *$ & -.098 & $-.155^{*}$ & $-.127 *$ & $-.189 *$ & -.038 & -.045 & -.093 & $-.162 *$ & $.288^{*}$ & $.239^{*}$ & $.280 * *$ & $.114 *$ & & & & & & & & \\
\hline 16. Size & 93 & 37 & -.046 & $-.105^{*}$ & -0.112 & $-.137 *$ & -.092 & -.056 & $-.193 *$ & -.092 & -.023 & -.003 & $.201 *$ & $.225 *$ & $.194 *$ & .015 & $.155^{*}$ & & & & & & & \\
\hline 17. International networks & 2.8 & 0.18 & -.002 & -.039 & -091 & -.074 & -.109 & -.083 & -.034 & -.065 & -.090 & -.007 & $.238^{*}$ & $.275^{*}$ & .018 & .092 & $.110^{*}$ & $.125^{*}$ & & & & & & \\
\hline 18. International turnover $(\%)$ & 59 & 17 & $-.177 *$ & $-.124 *$ & $-.204 *$ & $-.221 *$ & $-.137 *$ & -.099 & $-.107 *$ & $-.289 *$ & $-.112 *$ & $-.171 *$ & $.289^{* *}$ & $.260^{* *}$ & $.120^{*}$ & $.112 *$ & $.179 * *$ & $.101 *$ & .072 & & & & & \\
\hline 19. Geographical areas & 1.3 & 0.04 & .007 & .045 & .010 & -.099 & .028 & .037 & -.059 & .092 & .019 & .013 & .046 & .018 & -.059 & $.183^{*}$ & $.192 *$ & .044 & $.139 *$ & $.112 *$ & & & & \\
\hline 20. Equity/Non-Equity & 0.67 & 0.08 & .023 & .035 & .018 & .054 & .070 & .081 & .086 & .094 & .030 & .051 & .078 & .033 & -.062 & .058 & .029 & -.062 & -.048 & .034 & .002 & & & \\
\hline 21. Inter-sectorial & 0.11 & 0.02 & -.024 & .059 & .091 & .017 & .041 & .033 & .037 & .028 & .075 & .045 & .038 & .029 & .058 & -.045 & .067 & .056 & .014 & .072 & .009 & .058 & & \\
\hline 22. Manufacturing/ Service & 0.82 & 0.01 & -.033 & -.021 & .073 & -.082 & .022 & -.029 & .015 & -.045 & -.072 & -.081 & -.002 & -.066 & .025 & $.102 *$ & .035 & .010 & .038 & -.048 & .019 & .025 & .051 & \\
\hline 23. Intention & 4.7 & 0.59 & $-.119^{*}$ & $-.206^{* * *}$ & $-.182 *$ & $-.125^{*}$ & $-.143 *$ & $-.224 *$ & $-.203^{*}$ & $-.217^{*}$ & $-.120^{*}$ & $-.187 *$ & $.233^{*}$ & $.150^{*}$ & $.216^{*}$ & .078 & $.123 *$ & $.144 *$ & $.120 *$ & .075 & -.027 & .081 & .016 & .030 \\
\hline
\end{tabular}

${ }^{*} \mathrm{p}<0.10 ; * * \mathrm{p}<0.05 ; * * * \mathrm{p}<0.01$ 
Table 3. Hypotheses testing (Dependent variable: Intention)

\begin{tabular}{|c|c|c|c|c|c|c|c|c|}
\hline Variables & M1 & M2a & M2b & M3a & M3b & M4 & M5 & M6 \\
\hline \multicolumn{9}{|l|}{ Independent Variables } \\
\hline Selection (Reasons) & & -0.091 & & & & & & -0.025 \\
\hline Selection (Criteria) & & $-0.378 * *$ & $-0.331 * *$ & & & $-0.372 * *$ & & $-0.317 * *$ \\
\hline Selection (Channels) & & $-0.125^{*}$ & $-0.106^{*}$ & & & $-0.194 *$ & & $-0.224 *$ \\
\hline Selection (Contacts) & & -0.027 & & & & & & -0.011 \\
\hline Negotiation (Contract) & & & & $-0.203^{*}$ & $-0.156^{*}$ & $-0.161 *$ & & $-0.109 *$ \\
\hline Negotiation(Contribution) & & & & $-0.112 * *$ & $-0.184 *$ & $-0.165^{*}$ & & -0.197 \\
\hline Negotiation (Roles) & & & & -0.019 & & & & -0.015 \\
\hline Negotiation (Governance) & & & & -0.066 & & & & -0.021 \\
\hline Negotiation (Plan) & & & & $-0.155^{*}$ & $-0.107 *$ & $-0.183^{*}$ & & $-0.133 *$ \\
\hline Negotiation (Relation) & & & & $-0.192 *$ & $-0.187 *$ & $-0.150 *$ & & $-0.185^{*}$ \\
\hline Experience (Cooperation) & & & & & & & $0.205^{* *}$ & $0.201 * *$ \\
\hline Experience (Partner) & & & & & & & $0.307 * *$ & $0.302^{* *}$ \\
\hline Years international & & & & & & & & $0.156^{*}$ \\
\hline Experience (C) x Years & & & & & & & & $0.121 *$ \\
\hline Experience (C) xYears ${ }^{2}$ & & & & & & & & -0.090 \\
\hline \multicolumn{9}{|l|}{ Control Variables } \\
\hline International Skills & $0.207 *$ & $0.123 *$ & $0.174 *$ & $0.162 *$ & $0.166^{*}$ & $0.155^{*}$ & $0.110 *$ & $0.129 *$ \\
\hline International Orientation & $0.166^{*}$ & $0.189 *$ & $0.184 *$ & $0.205 * *$ & $0.266 * *$ & $0.194 *$ & $0.121^{*}$ & $0.254 *$ \\
\hline Size & $0.114 *$ & 0.087 & $0.104 *$ & $0.173 *$ & 0.095 & $0.199 *$ & $0.118^{*}$ & 0.020 \\
\hline International networks & $0.228 *$ & $0.194 *$ & $0.208 * *$ & $0.172 *$ & $0.155^{*}$ & $0.215^{*}$ & $0.150^{*}$ & $0.249^{*}$ \\
\hline International turnover & $0.192 *$ & $0.108 *$ & $0.115^{*}$ & $0.121 *$ & $0.141 *$ & $0.126^{*}$ & $0.217 *$ & $0.137 *$ \\
\hline Geographical areas & 0.003 & 0.075 & 0.030 & 0.013 & 0.024 & 0.077 & 0.015 & 0.060 \\
\hline Equity/Non-Equity & 0.025 & 0.037 & 0.041 & 0.086 & 0.014 & 0.009 & 0.031 & 0.037 \\
\hline Inter-sectorial & $0.102 *$ & 0.044 & 0.072 & 0.017 & 0.061 & 0.040 & 0.033 & 0.035 \\
\hline Manufacturing/ Service & $0.137 *$ & 0.099 & 0.032 & 0.075 & $0.109^{*}$ & 0.017 & 0.044 & 0.082 \\
\hline $\mathbb{R}^{2}$ (adjusted) & 0.308 & 0.421 & 0.399 & 0.485 & 0.383 & 0.468 & 0.302 & 0.511 \\
\hline
\end{tabular}

$* \mathrm{p}<0.10 ; * * \mathrm{p}<0.05 ; * * * \mathrm{p}<0.01$ 